\title{
Are the Ethical Committees for pharmacological research bureaucratic bodies?
}

\author{
Bruno Mario Cesana \\ Associate Professor of Medical Statistics, University of Brescia; President of the Ethical \\ Committee of Milan Area 3, Milan, Italy
}

\section{Background}

The question, reported in the title of this editorial, has the purpose of being intentionally a little provocative. It is obvious the Ethical Committees (CE), founded and established to approve clinical trials of new drugs that the pharmaceutical industry intends to market and, in general, biomedical research such as pharmaceutical no profit controlled clinical trials and observational studies, are Bureaucratic Bodies. Indeed, they are a group of people with various skills that work in compliance of well-defined rules and laws in order to realize the common good of health on the basis of criteria of impartiality, rationality, impersonality and, mostly relevant, independence; property, this latter, that it is not actually requested for a real Bureaucratic Body, but that is an essential requisite for an Ethical Committee. So, the answer can only be affirmative.

It is however equally obvious that the above question refers rather to the negative connotations of the term bureaucracy, such as an inefficient, convoluted, too inflexible structure perched on privileged positions to consider with extreme fussiness irrelevant aspects and to formulate unnecessary requests for themselves to meet absolutely non-substantial needs. Indeed, the current question arises from an e-mail sent to me by a researcher working in a hospital afferent to the CE Milan Area 3 (CEMiA-3).

The researcher's complaints and outburst were due to the fact that the CEMiA-3 did not immediately approved a study of which she/he was the Principal Investigator. Indeed a suspension judgement was expressed, requesting the clarification of several aspects and the completion of some relevant documents, among which, in the information sheet for the patients to be enrolled into the controlled clinical trial, it had to be reported the time and the place of conservation of the biological samples (now suspended by you because there is no written as long as we keep the samples and where: at the XY or XZ hospital! and it goes next year! Was not a phone call enough?, just for reporting the exact text). Furthermore, she/he wrote This CE would not be able to approve the discovery of the wheel or the fire for a thousand pretexts on the experimental plane or on the danger ... in short, it lacks courage and confidence in the talented Researcher and gets entrenched in the bureaucracy.

Obviously, the talented researcher with capital $R$, as she/he wrote, had only grasped the aspect of the conservation of the biopsy specimens which is, let me to say, a minor flaw compared to the shortcomings and mistakes that the CEs systematically find in the documentation of the studies submitted for their judgement.

However, it must be recognized that what the researcher wrote is a widely held opinion of the physicians/researchers who have to interact with the CEs and the aim of this Editorial is precisely that of trying to start to build a bridge of understanding and collabora- tion; indeed, it is clear that if the ECs and the researchers remain seated on the opposite banks of a river, they may perhaps recognize who it belongs the body that passes first in the river stream, but certainly they will never actively communicate.

I have to say that first of all I asked myself how it is possible to make clinical researcher understand that the EC do not make mere vexatious requests of a bureaucratic nature. I argued that, since the physicians member of the CEs, do not share this opinion but rather take it for granted that they are absolutely legitimate, a solution could be to impose a period of mandatory participation in the work of the ethics committees to all the clinicians and researchers. However, I must say, this solution could be impractical and even counterproductive.

In addition, I also wondered if it is ever possible to establish an active relationship of mutual collaboration between the CEs and the clinical researchers, given that every time the CE tried to do it through several workshops that I have proposed and contributed to organize for this purpose, the participation of researchers was extremely scarce and practically null.

I refer to the following three workshops held at the ASST Grande Ospedale Metropolitano Niguarda, Milan, Italy.

Workshop Il Comitato Etico di Niguarda e La Sperimentazione Clinica. 27th September 2006. [Niguarda's Ethics Committee and Clinical Trial].

Workshop del Comitato Etico dell'Azienda Ospedaliera Ospedale Niguarda Ca' Granda: Sperimentazioni Cliniche: Nuovo Decreto Ministeriale Clinical Trial Application (CTA). 29th September 2008. [Workshop of the Ethics Committee of the Hospital Agency Hospital Niguarda Ca' Granda: New Ministerial Decree Clinical Trial Application (CTA).

Workshop del Comitato Etico dell'Azienda Ospedaliera Ospedale Niguarda Ca' Granda: Validità del consenso informato ed applicabilità nelle situazioni critiche. Lo stato dell'arte degli aspetti normativi e le sfide per il futuro. 27th September 2012. [Workshop of the Ethical Committee of the Hospital Agency Hospital Niguarda Ca' Granda: Validity of informed consent and applicability in critical situations. The state of the art of regulatory aspects and challenges for the future.]

Finally, I refer to the recent conference: Quale prospettive per i Comitati Etici in Italia?, 1 December 2017, Bergamo, Italy. [Conference: What prospects for the Ethics Committees in Italy?]

\section{The requests of the ECs are bureaucratic acts?}

First of all, it has to be considered that the ECs are not sovereign and have to answer for their work to the Agenzia Italiana del Farmaco (AIFA, established by the Law 326 of 2003) ${ }^{1}$ 
to which the Law n.189 of 8 November 2012 recognizes the role of competent authority for the evaluation of clinical trials with drugs. ${ }^{2}$ Therefore, it seems that the EC has to play the role of being a kind of interface between researchers and AIFA trying to prevent that AIFA does not approve their trials with drugs.

In addition, as also the so-called Balduzzi Decree points out, ${ }^{3}$ the ECs must take their actions and issue their judgements by inspiring to non-normative reference documents such as: i) The Helsinki Declaration, 2013; ${ }^{4}$ ii) The Oviedo Convention, ${ }^{5}$ which was ratified in Italy by the law of 28 March $2001,{ }^{6}$ but this ratification has not yet been filed making it practically ineffective in Italy; indeed, it has to do a subsequent deposit of the instrument of ratification in the Council of Europe for making this ratification effective $;{ }^{7}$ iii) the rules of " good clinical practice $(\mathrm{GCP}) ;{ }^{8,9} \mathrm{iv}$ ) the updated guidelines of the European Agency (EMA) such as the ICH E8, ${ }^{10}$ the ICH E9, ${ }^{11}$ with its revision ICH E9(R1); ${ }^{12}$ v) but also, and above all, the laws of the Italian State such as the Legislative Decree of 24 June 2003 n $211 .^{13}$

The requests, such as those that have triggered the protests of the researcher, are carried out on specific current indications of the Guarantee of Privacy such as i) the authorization No. 9/2016, ${ }^{14}$ that considers the conservation of data and samples together with their security referring also to ii) the provision of 24 July $2008,{ }^{15}$ which also takes into account the problems of the data transfer abroad and the relevant ways to inform patients; iii) the Authorization 8/2016 concerning genetic data also in the field of research, ${ }^{16}$ with the problem related to the request of a further consent ranging from the broad consent to the blanket consent for future genetic investigations also considered, together with the topic of the biobanks in the biomedical research, by relevant guidelines of the National Bioethics Committee. ${ }^{17}$ About this point, it cannot be left out the famous guideline written in 2006 by the Smith Kline foundation and the Italian Society of Human Genetics, ${ }^{18}$ even if it is aimed primarily at genetic studies that are completely different from the socalled "substudies" on genotypes of patients primarily aimed at identifying potential prognostic factors, usually proposed as a corollary in controlled clinical trials, particularly in oncology.

Then, also the request to include in the information sheet at least the details of the insurance policy is a minimum requirement compared to the requirements of the Decree July 14, 2009 on insurance (the investigator is always required to inform the participants to the trial protocol, even through the informed consent... Article 1, Point 6). ${ }^{19}$ It has to point out that, according to the Decree, the ECs judgement is null by law in the absence of an appropriate insurance policy. It has also to be reported that the ECs are so blind bureaucrats that they almost usually accept the formal commitment of the sponsors to take out an appropriate insurance once the favourable judgement has been obtained, since it seems acceptable and sensible that the sponsors face additional economic charges only if they are appropriate.

In conclusion, these requests are to be considered absolutely in line with the principles of GCP and their revision to which the ECs inspire their work, ${ }^{8,9}$ principles that can be extended to other types of studies in addition to the controlled clinical trials on medicinal products

Thus, ECs demands must be considered not as the expression of a boring and dull bureaucracy, but rather as the expression of attention, consideration and respect towards a patient who is required to express informed consent consciously and freely. Indeed, it has to point out that the first mission of the ECs is the guarantee and protection of the patient, who constitutes the weakest and most suggestible link in the chain: patient, medical Researcher, AIFA, ethical committee, Pharmaceutical Industry, CRO, etc.
As a further comment, it is curious that the researchers do not complain so wildly about the strict rules, such as the fixed number of words, when they fill the application forms for obtaining funds for their research from some Agencies such as Telethon, Cariplo, Regione Lombardia, AIFA, International Agency For Research on Cancer (IARC), Horizon 2020, European Funds, Progetti di Ricerca di Interesse Nazionale (PRIN), etc.

\section{The adherence to the laws of the country can be considered a bureaucratic act?}

In addition to bureaucrats only able to put the sticks in the wheels, the ECs are also considered cowards when they do not authorize the so-called deferred consent in the case of an adult unable to express her/his informed consent and without a legal representative. In particular the EC, established by the Decree of 15 July 1997, Article $4,{ }^{20}$ were regulated by the Decree of March 8 , 1998 which, ${ }^{21}$ at point 3.7 .8 considered the so-called deferred consent to be acceptable following the ICH E6 GCP. ${ }^{8}$ Indeed, the ICH E6 guideline defines the informed consent at the point $1.28,{ }^{8}$ devoting to this topic a large space compared to the randomization, for example, which is considered only in a short five lines paragraph, and, finally, consider the deferred consent at the point 4.8.15. However, in the subsequent Decree 211 of 24 June 2003, ${ }^{22}$ the deferred consent is no longer considered acceptable as can be seen in Article 3 where only the legal representative of the person who is not able to providing informed consent is entitled to provide it in its place and also with particular limitations considered in the following Article 5.

\section{How much and where the problems, misunderstandings and conflicts between the ECs and the researchers are more relevant?}

I have to point out that the requests of the ECs are particularly relevant and numerous in the context of the research on medicinal products so-called no profit (characteristics that the CEs must carefully verify) that, according to the 15th AIFA Report on Clinical Trials in Italy, ${ }^{23}$ constitutes just a little less than a third of all the studies. In addition, this kind of research is particularly supported by the legislator with the Decree 17 December $2004^{24}$ and also with the recent Law Lorenzin. ${ }^{25}$

Indeed, the research no profit or independent presents the greatest criticality as researchers have to face a series of obligations that require specific skills, adequate equipment and the necessary funds: perhaps, the funds given by the pharmaceutical industry, as occurs in various circumstances, should be intended for the involvement of an Organizzazione di Ricerca a Contratto $(\mathrm{CRO})^{26}$ to support all the aspects of the planning and conducting a research.

I am convinced and I want to support the thesis that in reality the researchers $R$ capital with or without talent do not necessarily have to be aware of all the specific and detailed aspects that are associated with the drafting of documents to be set up for the request of the CEs judgement. In fact the researchers have to be fully supported in the path that runs from the conception of an idea (more or less spontaneously matured) to the presentation of the appropriate documentation to the ECs.

To this regard, I want to remember the Fondazione per la Ricerca Ospedale Maggiore di Bergamo (FROM) a non-university foundation at the ASST Papa Giovanni XXIII, and the recently 
founded Dipartimento di formazione e ricerca at the ASST Grande Ospedale Metropolitano Niguarda having precisely the aforementioned tasks and purposes.

In addition, I like to particularly mention the AIFA project of a few years ago, called the quality in non-profit clinical experimentation, ${ }^{27}$ in which the characteristics necessary for the establishment of a Clinical Trial Quality Team (CTQT) were identified, defining its composition, operational details and skills, and also the timing of activation and implementation of its activities.

I firmly believe that these structures of which there is a list dating back to 2010 of a dozen centres, especially placed in Istituti di Ricovero e Cura a Carattere Scientifico (IRCCS) and Universities with characteristics similar to the Clinical Trials Unit set up abroad, almost exclusively at University level and gathered in a specific network (website: http://www.ukcrc-ctu.org.uk/2, constitute the only way to overcome problems of misunderstandings and conflicts, to relieve the EC from an activity of mere control that diminishes its mission and its work and to win the challenge of independent and effectively no profit research that researchers cannot face alone as a trans-oceanic solitaire.

Correspondence: Bruno Mario Cesana, University of Brescia, Viale Europa 11, 25123, Brescia, Italy.

Email: brnmrcesana@gmail.com

Key words: Ethical Committees; bureaucratic bodies; pharmacological research; Italy.

Acknowledgements: Part of this paper has been presented as an oral communication entitled "I Comitati Etici per la ricerca: Organismi Burocratici?" at the workshop: "Quali prospettive per i Comitati Etici in Italia?" held in Bergamo, Italy 1 December 2017. This text represents the personal point of view of the author and not that of the Ethical Committee Milan Area 3.

Received for publication: 2 January 2018.

Accepted for publication: 2 January 2018.

CC Copyright B.M. Cesana, 2017

Licensee PAGEPress, Italy

Journal of Public Health Research 2017;6:1340

doi:10.4081/jphr.2017.1340

This work is licensed under a Creative Commons Attribution NonCommercial 4.0 License (CC BY-NC 4.0).

\section{References}

1. Italian Regulation. Ministry of Health. Law 326/2003. Official Journal n. 274, Ordinary Supplement n. 181. 25 November 2003.

2. Italian Regulation. Ministry of Health. Law 8 November 2012 , n.189. Official Journal n. 263, Ordinary Supplement n. 201/L. 10 November 2012.

3. Italian Regulation. Ministry of Health Decree 8 February 2013. Official Journal n.96, 24 April 2013.

4. World Medical Association. Dichiarazione di Helsinki Principi etici per la ricerca biomedica che coinvolge gli esseri umani. Evidence 2013;5:e1000059. Available from: www.evidence.it/ articoli/pdf/e1000059.pdf

5. Convention for the Protection of Human Rights and Dignity of the Human Being with regard to the Application of Biology and Medicine: Convention on Human Rights and Biomedicine Oviedo, 4.IV.1997. Available from: www.iss.it/binary/coet/ cont/ ConvenzioneOviedo.pdf

6. Italian Regulation. Law 28 March 2001 n. 145. Official Journal n. 95, 24 April 2001.
7. Act of Inspection Union No. 1-00778 Act no. 1-00778 Published on April 11th, 2017, in the session n. 805. Available from: http://www.senato.it/japp/bgt/showdoc/showText? tipodoc $=$ Sindisp\&leg $=17 \&$ id $=1012024$

8. ICH Steering Committee. ICH Guideline for Good Clinical Practice E6(R1) Current Step 4 version dated 10 June 1996. Available from: https:/www.ich.org/fileadmin/ Public_Web_Site/ICH_Products/Guidelines/Efficacy/E6/E6_ R1_Guideline.pdf

9. Committee for Human Medicinal Products Guideline for good clinical practice E6(R2) Step 5 EMA/CHMP/ICH/135/1995. 1 December 2016. Available from: http://www.ema.europa.eu/ ema/index.jsp?curl=pages/regulation/general/general_content_001251.jsp. Accessed on: December, 15, 2017.

10. $\mathrm{ICH}^{-}$Steering Committee. ICH Harmonised Tripartite Guideline General Considerations For Clinical Trials E8 recommended for Adoption at Step 4 of the ICH Process on 17 July 1997 Available from: http://www.ich.org/products/guidelines/efficacy/efficacy-single/article/general-considerationsfor-clinical-trials.htm. Accessed on: December, 15, 2017.

11. ICH Steering Committee. ICH Harmonised Tripartite Guideline Statistical Principles For Clinical Trials E9 Current Step 4, version dated 5 February 1998. Available from: http:/www.ich.org/products/guidelines/efficacy/efficacy-single/article/statistical-principles-for-clinical-trials.html. Accessed on: December, 15, 2017.

12. ICH Steering Committee. Final Concept Paper E9(R1): Addendum to Statistical Principles for Clinical Trials on Choosing Appropriate Estimands and Defining Sensitivity Analyses in Clinical Trials dated 22 October 2014 Endorsed by the ICH Steering Committee on 23 October 2014. Available from: http://www.ich.org/fileadmin/Public_Web_Site/ ICH_Products/Guidelines/Efficacy/E9/E9_R1_Final_Conce pt_Paper_October_23_2014.pdf

13. Italian Regulation. Legislative Decree 24 June 2003, n. 211. Official Journal n. 184, 9 August 2003 - Ordinary Supplement n. 130.

14. Italian Data Protection Authority. Autorizzazione n. 9/2016 Autorizzazione generale al trattamento dei dati personali effettuato per scopi di ricerca scientifica. 15 December 2016 (Registro dei provvedimenti n. 534, 15 December 2016)

15. Italian Data Protection Authority. Linee guida per il trattamento dei dati personali nell'ambito delle sperimentazioni cliniche di medicinali 24 July 2008 (Registro delle deliberazioni n. 52, 24 July 2008).

16. Italian Data Protection Authority. Autorizzazione n. 8/2016 Autorizzazione generale al trattamento dei dati genetici - 15 December 2016, Official Journal n. 303, 29 December 2016 (Registro dei provvedimenti n. 530, 15 December 2016).

17. National Committee on Bioethics, National Commette for Bioensurance, Biotechnology and Life Sciences. Collection of biological samples for research purposes: informed consent. 16 February 2009.

18. Fondazione Smith Kline, Società Italiana di Genetica Umana. Linee Guida per i protocolli clinici di Ricerca Genetica. Available from: http://www.fsk.it/download/Content/ Documentigd1/5962/o/lineeguidaricgenverseletrravanzata.pdf

19. Italian Regulation Ministry of Health. Decree 14 July 2009. Official Journal n. 213. 14 September 2009.

20. Italian Regulation. Ministry of Health. Decree 15 July 1997. Official Journal n. 191, 18 August 1997. Ordinary Supplement n. 162

21. Italian Regulation. Ministry of Health. Decree 18 March 1998. Official Journal n. 122. 28 May 1998. 
22. Italian Regulation. Ministry of Health Legislative Decree 24 June 2003, n.211. Official Journal n. 184. 9 August 2003.

23. Italian Medicines Agency $15^{\circ}$ Rapporto Nazionale AIFA sulla Sperimentazione Clinica dei medicinali in Italia. Availabile from: http://www.aifa.gov.it/content $/ 15 \% \mathrm{C} 2 \% \mathrm{~B} 0$-rapportonazionale-aifa-sulla-sperimentazione-clinica-dei-medicinaliitalia. Accessed on: December, 15, 2017.

24. Italian Regulation. Ministry of Health Decree 17 December 2004. Official Journal n.43. 22 February 2005.

25. Italian Regulation. Law "Lorenzin" (ex. Disegno di Legge N. 1324-B). Delega al Governo in materia di sperimentazione cli- nica di medicinali nonché disposizioni per il riordino delle professioni sanitarie e per la dirigenza sanitaria del Ministero della salute. Approved 22 December 2017, [to be published on the Official Journal].

26 Italian Regulation Ministry of Health Decree 15 November 2011. Official Journal n. 11, 14 January 2012.

27. Italian Medicines Agency. La qualità nelle sperimentazioni non-profit: Progetto AIFA. Available from: http://www.aifa. gov.it/content/la-qualit\%C3\%A0-nelle-sperimentazioni-nonprofit-progetto-aifa 